\title{
Penerapan Senam Kegel Untuk Menurunkan Inkontinensia Urine Pada Lansia
}

\author{
Oktavia Khamidah ${ }^{1 *}$, Herni Rejeki ${ }^{2}$ \\ 1,2 Program Studi Diploma Tiga Keperawatan, Fakultas Ilmu Kesehatan, Universitas \\ Muhammadiyah Pekajangan Pekalongan, Indonesia \\ *email: koktavia60@gmail.com
}

\begin{abstract}
When someone is getting older, usually she has some change, whether physical, biological, psychological, and mental ones. One of the physical changes is urinary incontinence disorder. It is uncontrolled release of urine that causes hygiene and social problems. This paper whitten to apply kegel exercises to reduce urinary incontinence disorder in elderly. It focused on two families with elderly who get this disorder. The result shows both cannot control their urination into the restroom. After applying the intervention, the first one still cannot control, yet. However, the second one has succeeded in controlling his urination, until he went to the restroom. Thus, it could be concluded this exercises is able to reduce urinary incontinence in elderly. Therefore, it is expected for them to practice it regularly.
\end{abstract}

Keywords: urinary incontinence, elderly, kegel exercise

\begin{abstract}
Abstrak
Menua biasanya mengalami perubahan-perubahan, baik perubahan fisik biologis maupun psikologis dan mental. Salah satu perubahan fisik pada lansia yaitu mengalami gangguan inkontinensia urine. Inkontinensia urine adalah keluarnya urin yang tidak terkontrol sehingga menyebabkan gangguan kebersihan dan sosial. Karya Tulis Ilmiah ini bertujuan untuk menerapkan senam kegel untuk menurunkan inkontinensia urine pada lansia. Fokus studi kasus pada karya tulis ilmiah ini adalah 2 keluarga dengan lansia yang mengalami inkontinensia urine. Hasil menunjukkan sebelum intervensi kedua pasien tidak dapat menahan BAK sampai ke kamar mandi. Setelah intervensi pada pasien 1 dapat menahan BAK belum dapat menahan sampai ke kamar mandi. Sedangkan pada pasien 2 dapat menahan BAK sampai ke kamar mandi. Kesimpulannya senam kegel dapat menurunkan inkontinensia urine pada lansia. Saran bagi pasien untuk melakukan senam kegel dengan rutin dan teratur.
\end{abstract}

Kata kunci: Inkontinensia urine; lansia; senam kegel

\section{Pendahuluan}

Menua (aging) biasanya mengalami perubahan-perubahan baik perubahan fisik biologis maupun psikososial dan mental. Perubahan fisik tersebut diantaranya adalah penurunan sel, penurunan system indra, sistem persyarafan, system kardiovaskuler, system respirasi, sistem perkemihan, sistem gastrointestinal, sistem reproduksi, sistem integumen dan system muskuloskeletal. Perubahan-perubahan mental pada lansia yaitu terjadi perubahan kepribadian, memori atau ingatan dan perubahan intelegensi. Perubahan psikososialnya yaitu dapat berupa kehilangan pekerjaan, kesepian dan kehilangan pasangan (Darmojo\&Soetojo, 2006 dalam jurnal Sutarmi, Setyowati \& Astuti, 2016).Perubahan - perubahan tersebut dapat mengakibatkan proses menua dan berpengaruh pada salah satu sistem pada lansia yaitu saluran kemih bagian bawah. Perubahan yang terjadi tersebut menjadi faktor utama bagi lansia untuk mengalami gangguan inkontinensia urin.

Inkontinensia urin merupakan salah satu gejala penyakit yang sering ditemukan pada pasien geriatri. Dapat diperkirakan prevalensi inkontinensia urin sekitar $15-30 \%$ 


\section{Prosiding Seminar Nasional Kesehatan $\mathbf{2 0 2 1}$ Lembaga Penelitian dan Pengabdian Masyarakat Universitas Muhammadiyah Pekajangan Pekalongan}

usia lanjut di masyarakat, 20-30\% pasien lansia dirawat di rumah sakit dengan masalah inkontinensia urin, dan saat berumur 65-74 tahun inkontinensia urin kemungkinan bertambah besar sekitar 25-30\%. Angka kejadian masalah inkontinnensia bertambah dua kali lipat pada wanita daripada pria (Aspiani, 2014).

Jumlah penderita inkontinensia urin di Indonesia sangat signifikan. Pada tahun 2006 diperkirakan jumlah penduduk yang mengalami inkontinensia urin sekitar 5,8\%, tetapi tidak ada penanganan yang layak. Hal ini dikarenakan masyarakat belum tahu tempat yang tepat untuk berobat serta kurangnya pengetahuan tenaga kesehatan tentang inkontinensia urin (Depkes, 2012).

Menurut Newman \& Smith, 1992; Taylor \&Handerson, 1986, terdapat salah satu cara yang dapat digunakan untuk meningkatkan atau memperbaiki kemampuan berkemih yaitu latihan otot dasar panggul (pe/vic muscte exercise) atau sering disebut senam kegel. Latihan kegel adalah latihan dasar panggul yang turut mengontraksikan tulang otot pubkosigeus, otot pembentuk struktur penyokong panggul, serta otot yang mengelilingi pintu panggul yaitu pada vagina, uretra, dan rectum (Maas et al, 2011 dalam Karjoyo dkk, 2017).

Studi pendahuluan yang dilakukan terhadap 4 lansia yang mengalami inkontinensia urin belum melakukan tindakan untuk pencegahan inkontinensia urin yaitu senam kegel. Sehingga studi kasus ini dilakukan untuk melakukan tindakan penanganan yang tepat pada penderita inkontinensia urin dan dapat teratasi serta dapat meningkatkan fungsi kandung kemih dalam mengatur aliran urin.

\section{Metode}

\section{Jenis Penelitian}

Rancangan karya tulis ilmiah ini adalah deskriptif dalam bentuk studi kasus. Studi kasus merupakan bentuk studi kasus tentang lingkungan social termasuk juga manusia di dalamnya yang mendalami secara mendalam (Sondak, Taroreh, Uhing, 2019). Studi kasus ini dilakukan dengan mencocokan pola, membangun penjelasan, serta model logis dan hasil dari pembahasan kasus ini nantinya di temukan beberapa hal yang mempengaruhi keberhasilan penerapan senam kegel pada lansia yang mengalami inkontinensia urine.

\section{Lokasi dan Waktu Penelitian}

Studi kasus ini telah dilakukan di Desa Singokerten Rt 02 Rw 4 Kauman Batang dimulai dari bulan April sampai Mei 2021

\section{Populasi dan Sampel}

Pengambilan sampel menggunakan Non probability sampling dengan teknik Purposive sampling, jumlah sampel pada penelitian ini sebanyak 4 responden sesuai criteria sampel. Pengambilan data dilakukan dengan menyeleksi calon responden yang sesuai dengan criteria sampel. Instrumen yang digunakan adalah lembar catatan dan meteran.

\section{Hasil dan Pembahasan}

\section{Hasil}

Hasil studi kasus yang telah dilakukan terhadap 2 keluarga yaitu dengan masalah inkontinensia urine di Desa Singokerten Kecamatan Batang Kabupaten Batang menggunakan pendekatan Asuhan Keperawatan yang meliputi pengkajian, diagnosa keperawatan, rencana keperawatan, implementasi, dan evaluasi. Implementasi difokuskan pada penerapan senam kegel untuk menurunkan inkontinensia urine. 


\section{Prosiding Seminar Nasional Kesehatan 2021 Lembaga Penelitian dan Pengabdian Masyarakat Universitas Muhammadiyah Pekajangan Pekalongan}

Pengkajian yang dilakukan pada kasus 1 yaitu klien mengatakan mempunyai riwayat operasi kanker kandungan sudah 15 tahun yang lalu, riwayat melahirkan per vagina, klien mengeluh tidak dapat menahan BAK, klien juga mengatakan terkadang ketika bersin atau batuk urin tidak dapat tertahan sehingga keluar. Dari hasil pengkajian fokus klien tidak dapat menahan BAK sehingga sering mengalami urin keluar sebelum sampai ke kamar mandi. Selama mengalami hal tersebut klien belum melakukan tindakan apa-apa dan tidak mengetahui cara yang dilakukan untuk mengatasi masalah tersebut.Hasil pengkajian status fungsional klien 1 dalam melakukan aktivitas sehari-hari terdapat pada skore A yaitu kemandirian dalam makan, kontinen, berpindah, ke kamar mandi, dan mandi. Sedangkan pada pengkajian status kognitif dan afektif pada klien I mengalami gangguan intelektual ringan.

Pengkajian yang dilakukan pada kasus 2 yaitu klien mengatakan mempunyai riwayat melahirkan per vagina, klien mengeluh terkadang tidak dapat menahan BAK sebelum sampai ke kamar mandi. Dari hasil pengkajian fokus klien tidak dapat menahan BAK sehingga sering mengalami urin keluar sebelum sampai ke kamar mandi. Selama mengalami hal tersebut klien belum melakukan tindakan apa-apa dan tidak mengetahui cara yang dilakukan untuk mengatasi masalah tersebut. Hasil pengkajian status fungsional klien 2 dalam melakukan aktivitas sehari-hari terdapat pada skore A yaitu kemandirian dalam makan, kontinen, berpindah, ke kamar mandi, dan mandi. Sedangkan pada pengkajian status kognitif dan afektif pada klien I mengalami gangguan intelektual ringan.

Pengkajian yang telah dilakukan terhadap 2 keluarga dirumuskan diagnosis keperawatan yaitu inkontinensia urinarius fungsional dan defisit pengetahuan. Rencana keperawatan yang akan dilakukan pada keluarga 1 dan 2 yaitu: 1) Monitor eliminasi urin yang meliputi frekuensi, volume, bau, dan warna urin, 2) Berikan pendidikan kesehatan tentang inkontinensia urin, 3) Ajarkan latihan otot dasar panggul atau senam kegel, 4) Anjurkan minum yang adekuat pada siang hari minimal $1500 \mathrm{cc}$ per hari, 5) Kolaborasi dengan keluarga untuk pemantauan waktu berkemih dan proses berkemih.

Implementasi pada 2 keluarga difokuskan pada tindakan senam kegel untuk menurunkan inkontinensia urine. Pada kasus 1 dan kasus 2 dilakukan tindakan selama 4 minggu dengan latihan 3 kali setiap hari. Jumlah latihan yang dilakukan yaitu 90 kali pertemuan. Hasil implementasi yang dilakukan penulis selama 1 minggu atau 21 kali pertemuan hasilnya adalah klien 1 dapat menahan BAK dengan jarak 1,5 meter sedangkan klien 2 dapat menahan BAK dengan jarak 2 meter. Tindakan selanjutnya diserahkan kepada anaknya untuk mengajari klien dalam melakukan senam kegel setiap hari sehari 3 kali. Penulis melakukan evaluasi 3 kali dalam seminggu.

\section{Pembahasan}

Penulis melakukan pembahasan dari hasil yang diuraikan diatas tentang penerapan senam kegel pada lansia dengan masalah inkontinensia urine di Desa Singokerten Kecamatan Batang Kabupaten Batang. Dari asuhan keperawatan yang sudah penulis lakukan dalam pembahasan studi kasus ini penulis didukung oleh referensi sesuai bab 2 . 


\section{Prosiding Seminar Nasional Kesehatan 2021 Lembaga Penelitian dan Pengabdian Masyarakat Universitas Muhammadiyah Pekajangan Pekalongan}

Implementasi yang penulis lakukan terhadap 2 keluarga sesuai dengan rencana keperawatan penulis yaitu melatih senam kegel. Pada hari pertama dilakukan tindakan memonitor eliminasi urin yang meliputi frekuensi, volume, bau dan warna urin. Selanjutnya penulis melakukan tindakan memberikan pendidikan kesehatan tentang inkontinensia urin karena 2 keluarga tersebut belum mengetahui tentang inkontinensia urin dan cara yang tepat untuk mengatasi inkontinensia urin. Hal ini sejalan dengan data dari Depkes (2012), jumlah penduduk Indonesia yang mengalami inkontinensia urine sekitar 5,8\% tetapi tidak ada penanganan yang layak karena masyarakat belum tahu tempat yang tepat untuk berobat serta kurangnya pengetahuan tenaga kesehatan tentang inkontinensia urin.

Implementasi selanjutnya yaitu mengajarkan dan melatih cara senam kegel yang benar untuk menurunkan inkontinesia urin. Hal ini sesuai dengan pernyataan menurut Yuliana (2011) dalam Jurnal Ipteks Terapan (2017), senam kegel adalah senam untuk menguatkan otot panggul atau senam yang bertujuan untuk memperkuat otot-otot dasar panggul terutama otot pubococcygealsehingga seorang wanita dapat memperkuat otot-otot saluran kemih. Senam kegel juga dapat menyembuhkan ketidakmampuan menahan kencing (inkontinensia urine).

Latihan senam kegel yang dilakukan pada 2 keluarga ini dilakukan selama 4 minggu dengan latihan 3 kali setiap harinya. Jumlah pertemuan selama 4 minggu yaitu 90 kali latihan. Latihan dengan didampingi oleh penulis dari pertemuan ke 1 sampai dengan pertemuan ke 21 atau selama 1 minggu. Untuk pertemuan selanjutnya pasien latihan secara mandiri dengan didampingi dan diajari oleh anggota keluarga masingmasing, penulis hanya melakukan kunjungan kepada 2 keluarga tersebut 3 kali dalam seminggu untuk mengecek hasil latihan dan pengukuran jarak pasien dalam menahan BAK menuju ke kamar mandi.

Hasil setelah latihan senam kegel dari pertemuan ke 1 sampai ke 21 atau selama 1 minggu terjadi perubahan penurunan inkontinensia urin. Pertemuan ke 1 sampai ke 5 pasien belum mengetahui cara melakukan senam kegel dengan benar dan sering lupa cara melakukan senam kegel, sehingga belum ada hasil atau perubahan penurunan inkontinensia urin. Pada pertemuan ke 6 sampai ke 10 pasien sudah dapat melakukan senam kegel dengan benar namun belum terjadi perubahan penurunan inkontinensia urin karena inkontinensia urin harus dilakukan secara berulang-ulang dengan rutin dan teratur. Hal ini sesuai dengan penelitian yang dilakukan oleh Milya Novera dalam Jurnal Ipteks Terapan (2017), latihan senam kegel dilakukan secara berulang-ulang sebanyak 3-4 kali setiap hari selama 4 minggu.

Pertemuan ke 11 terjadi perubahan penurunan inkontinensia urine pada 2 keluarga yaitu pasien dapat menahan pengeluran urine atau BAK menuju ke kamar mandi dalam jarak 1 meter dari tempat klien. Hal ini sejalan dengan penelitian yang dilakukan oleh Hidayati (2009) dalam Jurnal Riset Kesehatan (2016), penelitian dilakukan di Panti Wreda Sindang Asih Semarang, kegel exerciseyang dilakukan sebanyak 10 kali dalam 3 minggu menyebabkan penurunan inkontinensia urine. Pada klien 1 dapat menahan BAK dengan jarak 1 meter dari pertemuan ke 11 sampai ke 17. Sedangkan pada klien 2 dapat menahan BAK dengan jarak 1 meter dari pertemuan ke 11 sampai ke 16. 


\section{Prosiding Seminar Nasional Kesehatan 2021 Lembaga Penelitian dan Pengabdian Masyarakat Universitas Muhammadiyah Pekajangan Pekalongan}

Pertemuan ke 18 pada klien 1 terjadi perubahan penurunan inkontinensia urine yaitu yang semula pada pertemuan ke 17 dapat menahan BAK ke kamar mandi dengan jarak 1 meter kini menjadi 1,5 meter. Pada jarak ini dapat dipertahankan oleh pasien 1 sampai pertemuan ke 21, sedangkan pada pasien 2 jarak ini dapat dipertahankan sampai pertemuan ke 20. Pada pasien 2 di pertemuan ke 21 mengalami perubahan jarak yaitu 2 meter. Hal ini terjadi karena pasien 2 melakukan latihan senam kegel lebih dari 3 kali dalam sehari. Ketika pasien 2 ingat untuk melakukan senam kegel maka ia melakukan dimanapun dan kapanpun. Hal ini dibenarkan menurut Milya Novera (2017), dalam penelitinya yaitu Pengaruh Senam Kegel Terhadap Frekuensi BAK pada Lansia dengan Inkontinensia Urine, lansia mengatakan senam kegel bukanlah suatu senam yang susah untuk dilakukan karena tanpa orang lain tahu sudah bisa untuk melakukan senam kegel dimana pun dan kapan pun dan saat melakukan apapun dapat dilakukan. Hal ini juga bisa dilihat dari hasil pengukuran selanjutnya pada klien 2 hasilnya lebih maksimal daripada klien 1.

Pertemuan ke 69 terjadi penurunan pengukuran jarak pada klien 1 dalam menahan BAK. Semula pada pertemuan-pertemuan sebelumnya pasien mengalami peningkatan jarak dalammenahan BAK dengan jarak 3 meter kini klien 1 dalam pertemuan ke 69 hanya dapat menahan BAK dengan jarak 2 meter. Hal ini dikarenakan klien 1 sering lupa untuk melakukan latihan senam kegel. Sehingga terjadi penurunan pengukuran jarak dalam menahan BAK. Hal ini dibenarkan menurut penelitian yang dilakukan oleh Rahajeng (2010) dalam e-journal keperawatan (2017) bahwa tanpa latihan otot dasar panggul atau senam kegel tidak akan ada perbaikan pada kekuatan otot panggul sehingga tidak terjadi penurunan inkontinensia urine.

Latihan senam kegel yang telah dilakukan terhadap 2 keluarga dengan inkontinensia urin selama 4 minggu, penulis mengevaluasi bahwa pada pasien 1 belum dapat menahan BAK sampai ke kamar mandi dan hanya dapat menahan BAK dengan jarak 3 meter. Hal ini disebabkan karena pada pasien 1 tidak melakukan latihan dengan teratur karena pasien mengalami penurunan daya ingat. Hal ini dibuktikan menurut Ratnawati (2017), perubahan pada sistem saraf otak lansia biasanya mengalami penurunan ukuran, berat, dan fungsi yang menyebabkan lambat dalam berespon dan berfikir serta cepat lupa dalam mengingat sesuatu. Rencana tindak lanjut pasien yaitu akan dikelola sampai masalah pasien teratasi atau sampai pasien dapat menahan BAK sampai ke kamar mandi dengan didampingi oleh keluarga pasien.

Hasil latihan senam kegel yang dilakukan pada pasien 2 dapat mencapai ke kamar mandi sebelum keluarnya urin. Hal ini karena pasien 2 melakukan senam kegel dengan rutin dan teratur dan melakukannya ketika kapan pun, dimana pun, dan ketika sedang melakukan apapun. Hal ini sesuai dengan penelitian yang dilakukan oleh Dahlan D.A (2014), latihan senam kegel yang dilakukan secara rutin dan teratur oleh para lansia memberikan manfaat yang sangat besar bagi kekuatan otot panggul lansia sehingga para lansia dapat mengontrol keinginan berkemih, penurunan frekuensi berkemih (inkontinensia urine). 


\section{Prosiding Seminar Nasional Kesehatan Lembaga Penelitian dan Pengabdian Masyarakat Universitas Muhammadiyah Pekajangan Pekalongan

\section{Kesimpulan}

Hasil dari penerapan senam kegel untuk menurunkan inkontinensia urin terjadi penurunan. Tindakan senam kegel harus dilakukan secara rutin dan teratur. Hasil latihan senam kegel pada 2 keluarga dengan inkontinensia urin selama 4 minggu didapatkan hasil yang berbeda. Pada pasien 1 belum dapat menahan BAK sampai ke kamar mandi karena pasien 1 sering lupa dalam melakukan senam kegel sehingga latihan tidak rutin dan tidak teratur. Sedangkan pada pasien 2 terjadi penurunan inkontinensia urin, pasien dapat menahan BAK sampai ke kamar mandi dengan jarak 4 meter.

\section{Referensi}

[1] Aspiani Reny Y., "Buku Ajar Asuhan Keperawatan Gerontik". Jakarta:Trans Info Media, 2014.

[2] Dahlan D.A. \& Martiningsih, "Pengaruh Latihan Kegel Terhadap Inkontinensia Urine pada Lansia di Panti Tresna Wherda Meci Angi Bima," Jurnal Kesehatan Prima, vol.8, no.2, pp 1292-1297, 2014.

[3] Jayanti, N.A., "Pengaruh Senam Kegel dan Pijat Perineum Terhadap Kekuatan Otot Dasar Panggul Lansia di Puskesmas Tabanan III," Skripsi Fakultas Kedokteran Universitas Udayana, 2015.

[4] Karjoyo, J.D, Pangemanan, D., Onibala, F., "Pengaruh Senam Kegel terhadap Frekuensi Inkontinensia Urine pada Lanjut Usia di Wilayah Kerja Puskesmas Tumpaan Minahasa Selatan," E-journal Keperawatan, vol.5, no.1, 2017.

[5] Kholifah, S.N., "Keperawatan Gerontik," in pusdiksdmk/wpcontent/upload/2017/Keperawatan-Gerontik-Komprehensif.pdf, 2017.

[6] Novera, M., "Pengaruh Senam Kegel Terhadap Frekuensi BAK pada Lansia dengan Inkontinensia Urine," Jurnal IPTEK Terapan, vol.7, no.3, pp 240-245, 2017.

[7] Dewi Puspasari, "Efektivitas Latihan Kegel Dalam Mengatasi Keluhan Disperesia dan Kesulitan Orgasme pada Perempuan Pasca Terapi Kanker Serviks," Fakultas Kedokteran, Universitas Indonesia, 2011.

[8] Ratnawati, E., "Asuhan Keperawatan Gerontik,".Yogyakarta: Pustaka Baru Press, 2017.

[9] Sutarmi, Setyowati, T., \& Astuti, Y., "Pengaruh Latihan Kegel Terhadap Frekuensi Inkontinensia Urin Pada Lansia di Unit Rehabilitasi Sosial Margo Mukti Rembang," Jurnal Riset Kesehatan, vol.5, no.1, pp 1-6, 2016.

[10] Utama, H., "Buku Ajar Boedhi-Dharmojo Geriatri," .Jakarta: Balai Penerbit Fakultas Kedokteran Universitas Indonesia, 2011. 